\title{
Efficacy of Myrmecodia Platytyrae (MyP) Water Extract in Reducing Cholesterol Level in Hypercholesterolemia Induced Sprague Dawley Rat
}

\author{
M. K. Nik Hasan ${ }^{1 *}$, I. Abdul Wahab², H. H. Mizaton ${ }^{3}$, M. A. Rasadah ${ }^{4}$ \\ ${ }^{1,2,3}$ Faculty of Pharmacy, Universiti Teknologi MARA (UITM), Bandar Puncak Alam, Selangor, 42300, MALAYSIA \\ ${ }^{4}$ Natural Product Division, Forest Research Institute Malaysia, 52109 Kepong, Darul Ehsan, Selangor, MALAYSIA \\ *Email for Correspondence: mohdkamal@ frim.gov.my
}

\begin{abstract}
Myrmecodia plant or ant-nest plant is from Rubiaceae family. Rubiaceae are mainly tropical woody plants, consist mostly of trees and shrubs and can be found in temperate regions. Myrmecodia platytyrea $(M y P)$ are believed to have medicinal value. This study was designed in order to investigate the effect of $M y P$ extract as anti hypercholesterolemic agent. The results showed that treatment of $M y P$ can significantly reduce $(\mathrm{p}<0.05)$ low density lipoprotein $(\mathrm{LDL})$ compared to negative control group. The extract was significantly increase $(\mathrm{p}<0.05)$ high density lipoprotein $(\mathrm{HDL})$ concentration compared to negative control group. Besides that, $M y P$ increased fecal cholesterol and fecal bile compared to normal control group. It was also found that lipid profile was significantly decreased $(\mathrm{p}<0.05)$ in $M y P$ treatment group. All biochemistry data showed that $M y P$ water extract was not toxic at all.
\end{abstract}

Keywords: Myrmecodia platytyrea, anti hypercholesterol, low density lipoprotein, high density lipoprotein

\begin{tabular}{llll}
\hline Manuscript Received: 15 April 2020 & - & Revised: 20 June 2020 & Accepted: 10 July 2020 \\
\hline \hline This article is is licensed under a Creative Commons Attribution-NonCommercial 4.0 International License. \\
Attribution-NonCommercial (CC BY-NC) license lets others remix, tweak, and build upon work non-commercially, and although the new works must also cC) (7) \\
acknowledge and be non-commercial.
\end{tabular}

\section{INTRODUCTION}

Hypercholesterolemia is a vital factor for the development of cardiovascular diseases such as atherosclerosis (Saba et al., 2016). Hypercholesterolemia is due to high levels of low-density lipoprotein (LDL) (de Isla et al., 2016) and frequently associated with low values of high-density lipoprotein (HDL) (Tolani et al., 2013). Oxidised low-density lipoprotein (ox-LDL) and endothelial dysfunction have been established to play a key role in atherosclerosis (Narasimhulu et al., 2016). In herbal plants, phenolic compounds have been shown to have beneficial antioxidant constituents for human health (Bordoloi et al., 2016; Šibul et al., 2016). Many polyphenolics exert more powerful antioxidant effect (Paun et al., 2016) and inhibit lipid peroxidation (Shodehinde et al., 2013). They can also directly scavenge reactive oxygen species (ROS), such as superoxide, peroxynitrite and hydroxyl radicals (Morita et al., 2016). Previous studies showed that compounds from the plant can directly decrease cholesterol production in liver cells (Cao et al., 2013; Hamidpour et al., 2015). Anticholesterol and antioxidant effects are two important characteristics of compounds that are needed in order to successfully reduce cholesterol related diseases (Xie et al., 2011; Hopkins et al., 2013; Ogunremi et al., 2015).

One of traditional medicine plant that was used by people of Papua New Guinea, Vietnam and Indonesia which is not well identified is Sarang semut or Myrmecodia (Soeksmanto et al., 2010). From this species, there are only Myrmecodia pendens (M. pendens) and Myrmecodia tuberose (M. tuberose) are believed to have medicinal value (Soeksmanto et al., 
2010). However, recently, Myrmecodia platytyrae (MyP) which is one of Myrmecodia genus was proven to have anticancer properties and not toxic to normal cell (Mizaton et al., 2010). Engida et al., (2013) reported that Myrmecodia genus contain high in flavonoid and act as good antioxidant. Recently, a study was done by Roslizawaty et al., (2015) showed that treatment of $100 \mathrm{mg}$ and $200 \mathrm{mg}$ ethanol Myrmecodia sp. extract can reduce cholesterol level in the rat that was induced with hypercholesterolemia. This animal laboratory study was done in order to determine the effect of $M y P$ water extract to contribute anticholesterol effects on hypercholesterolemic induced rat.

\section{MethOD}

\section{Preparation of $10 \% M y P$ Water Extract}

Ten percent $(10 \%)$ of $M y P$ water extract was prepared by adding $100 \mathrm{~g} M y P$ powder to $900 \mathrm{ml}$ distilled water and boiled at $100^{\circ} \mathrm{C}$ for 15 hours. The solution was filtered and the supernatant was concentrated by using rotavap at $50^{\circ} \mathrm{C}$. The processed $10 \%$ water extract of $M y P$ was stored at $-80^{\circ} \mathrm{C}$ until use.

\section{Induction of Hypercholesterolemia in Rats and its Treatment}

Experiments were approved by the Ethical Committee of the Institution Animal Care and Use Committee - Forest Research Institute Malaysia (IACUC-FRIM). Thirty-six male Sprague-Dawley rats ( 7 weeks old) were housed separately ( 3 animals/cage). The rat was kept in a temperature-controlled $\left(25 \pm 2^{\circ} \mathrm{C}\right)$ room with a regular $12 \mathrm{~h} \mathrm{light:} 12$ $\mathrm{h}$ dark cycle. After acclimatisation period for a week in this laboratory environment, all the rats were then randomly assigned to six experimental groups ( $\mathrm{n}=6$ for each group) like below:

A) Normal Control group (Normal) was fed with standard normal rat chow with protein $(\sim 14 \%)$, fat ( 10\%) and carbohydrate $(\sim 76 \%)$.

B) Negative Control group (NC) was fed with high cholesterol diet (HCD). The diet was formulated by using standard rat chow plus $60 \%$ pure cholesterol, $1 \%$ cholic acid and $5 \%$ peanut oil.

C) Positive Control group (PC) was Simvastatin treatment group. The PC group was fed with HCD and treated with $5 \mathrm{mg} / \mathrm{kg}$ Simvastatin.

D) The $100 \mathrm{mg} M y P$ water extract treatment group (MyP 100) was fed with HCD and treated with $M y P(100 \mathrm{mg} / \mathrm{kg})$.

E) The $200 \mathrm{mg} M y P$ water extract treatment group (MyP 200) was fed with HCD and treated with $M y P(200 \mathrm{mg} / \mathrm{kg})$.

F) The $400 \mathrm{mg} M y P$ water extract treatment group (MyP 400) was fed with HCD and treated with $M y P(400 \mathrm{mg} / \mathrm{kg})$.

All rats were given free access to water and their corresponding diet throughout the experimental period. Food intake and body weight were monitored every 1 week.

\section{Faecal Cholesterol Analyses}

At week 3, the faeces were collected during the last three days using metabolic cages and used to determine the faecal cholesterol. The faeces was dried, milled, and stored at $-80^{\circ} \mathrm{C}$ until used. For extraction process, $15 \mathrm{ml}$ of 3: 1 alcoholether mixture was added in a $25 \mathrm{ml}$ volumetric flask containing $0.5 \mathrm{mg}$ of faeces. The mixture was allowed to stand for $30 \mathrm{~min}$ at room temperature with occasional swirling and mixed by slow inversion at least ten times. The mixture was filtered through a Whatman No. 41 filter paper. Two millilitres aliquot was used for total cholesterol determination by using the kit.

\section{Faecal Bile Acid Analyses}

The faeces from individually housed rat were collected, weighed, and dried. Then $0.5 \mathrm{~g}$ of dried faeces was minced and extracted with $10 \mathrm{ml}$ of $75 \% \mathrm{EtOH}$ at about $50^{\circ} \mathrm{C}$ for $2 \mathrm{~h}$. The extract was centrifuged, and a $1 \mathrm{ml}$ sample of supernatant was diluted to $4 \mathrm{ml}$ with a $25 \%$ PBS solution for faecal bile assay. A number of faecal bile acids were determined enzymatically by using the bile acids kit (Sigma).

\section{Termination and Blood Collection}

At the end of the week 4 experimental period, animals subjected to 12 hours fasting period to allow relevant estimation of biochemical parameters. The animals were sacrificed by using diethyl ether. Blood sampling via cardiac puncture at an approximate volume of $8 \mathrm{ml}$ from each rat was drawn into EDTA tube for plasma preparation. The tubes were centrifuged at $3000 \mathrm{rpm}$ for 10 minutes at $25^{\circ} \mathrm{C}$. Plasma obtained from the centrifugation was aliquoted into Eppendorf tubes. All samples were stored at $-80^{\circ} \mathrm{C}$ until analysed.

\section{Biochemistry test}

The plasma was analysed its biochemistry profile by Roche commercial kit. The kit was used to measure the level of ALT, AST, ALP, Creatinine Kinase (CK) and Urea in the plasma using biochemistry analyzer at the Bioactivity Laboratory, Natural Products Division, FRIM. 


\section{Plasma Lipid Profile}

Analysis of lipid profile includes measuring TC, TG, LDL and HDL levels in the plasma by using Roche commercial kit.

\section{Statistical analysis}

All data are presented as means \pm standard deviation (SD), and $\mathrm{n}$ denotes the number of replications for each data point. Differences between groups were analysed using one-way analysis of variance (SPSS, Version 20). Post hoc tests were performed for inter-group comparisons and $p$ value of $<0.05$ was considered significant.

\section{RESULTS}

\section{Food Intake}

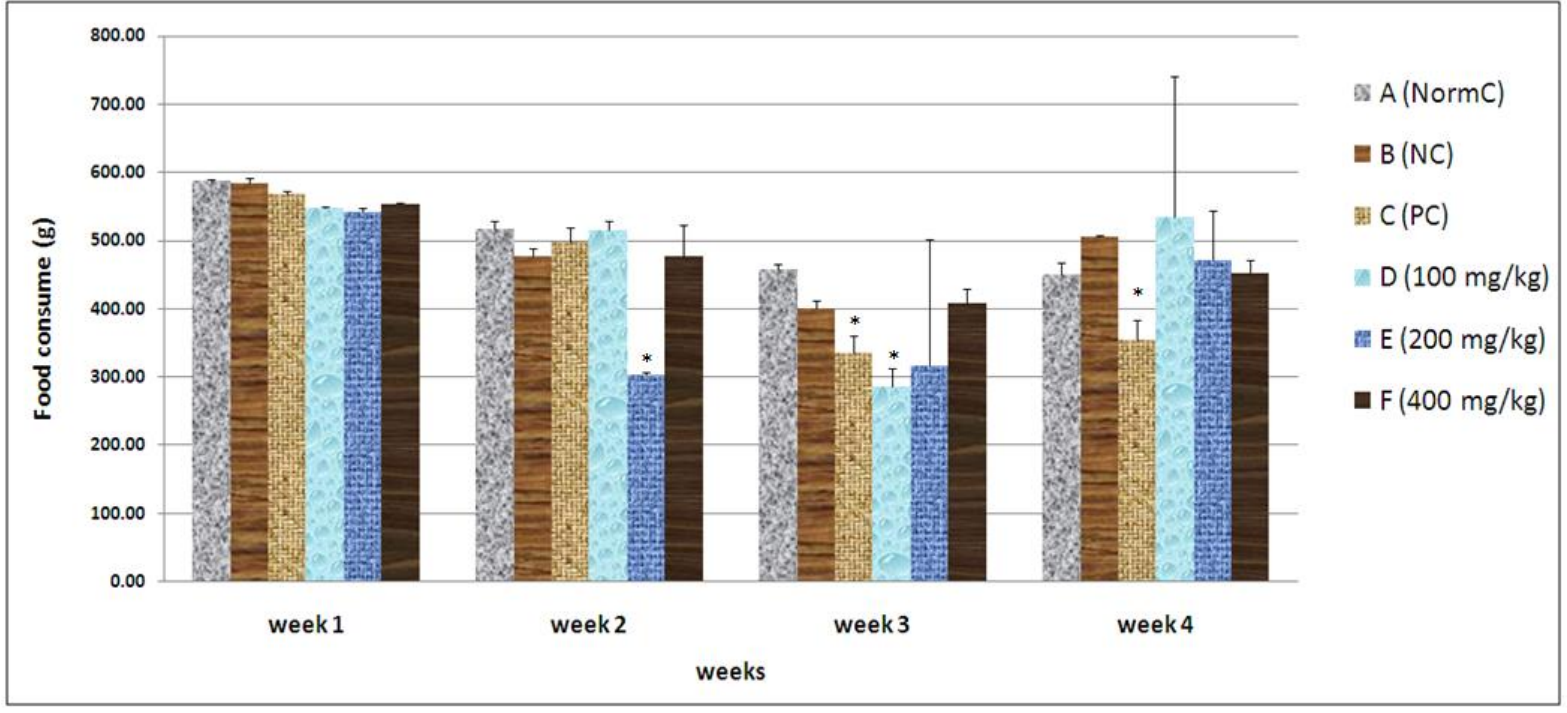

Figure 1. Food intake in rats treated with $M y P$ water extract for 4 weeks. Results are expressed as mean \pm S.D. Different superscripted letters on top of the chart indicate statistical differences $(p<0.05)$. Chart with an asterisk $\left(^{*}\right)$ symbol indicating significantly different from the normal control group $(\mathrm{p}<0.05)$ for each week. $\mathrm{n}=6$.

\section{Water Intake}

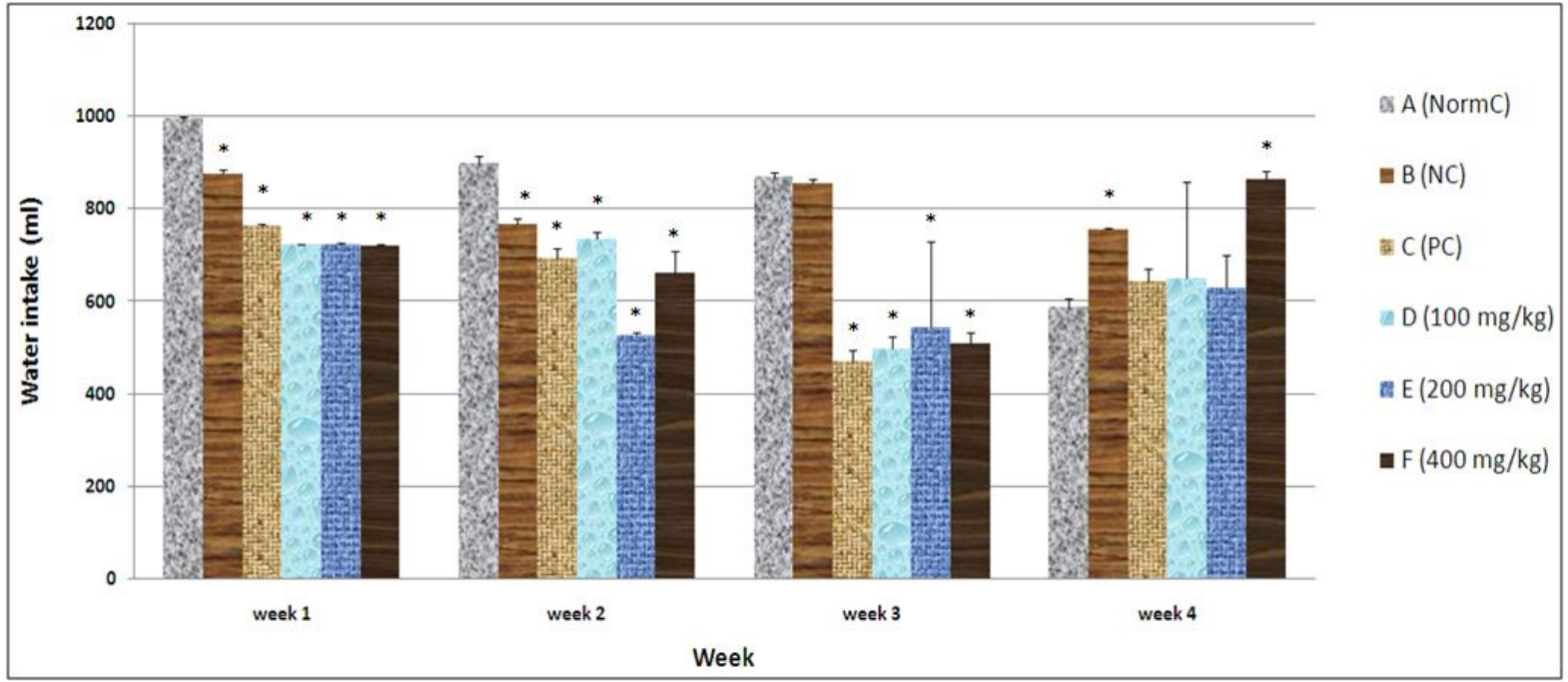

Figure 2. Water intake in rats treated with $M y P$ water extract for 4 weeks. Results are expressed as mean \pm S.D. Different superscripted letters on top of the chart indicate statistical differences $(p<0.05)$. Chart with an asterisk $(*)$ symbol indicating significantly different from the normal control group $(\mathrm{p}<0.05)$ for each week. $\mathrm{n}=6$. 


\section{Bodyweight}

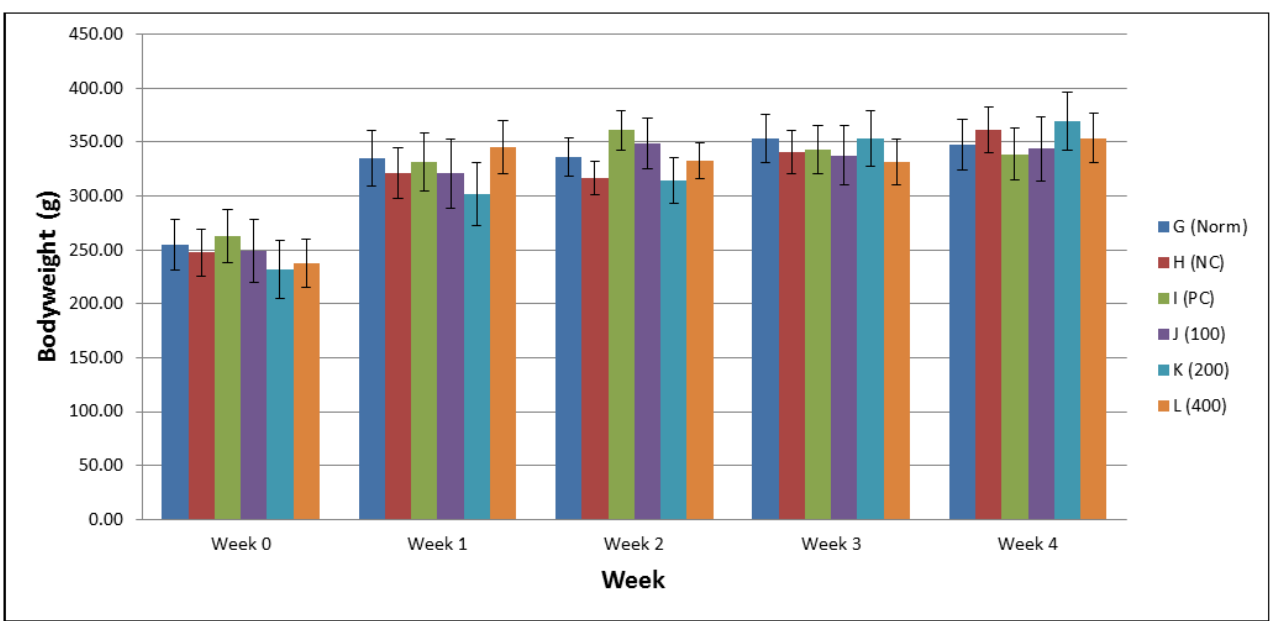

Figure 3. Body weight of rats treated with $M y P$ water extract for 4 weeks. Results are expressed as mean \pm S.D. Different superscripted letters on top of the chart indicate statistical differences $(p<0.05)$. Chart with an asterisk $\left(^{*}\right)$ symbol indicating significantly different from the control group $(\mathrm{p}<0.05)$ for each week. $\mathrm{n}=6$.

\section{Plasma Lipid Profile}

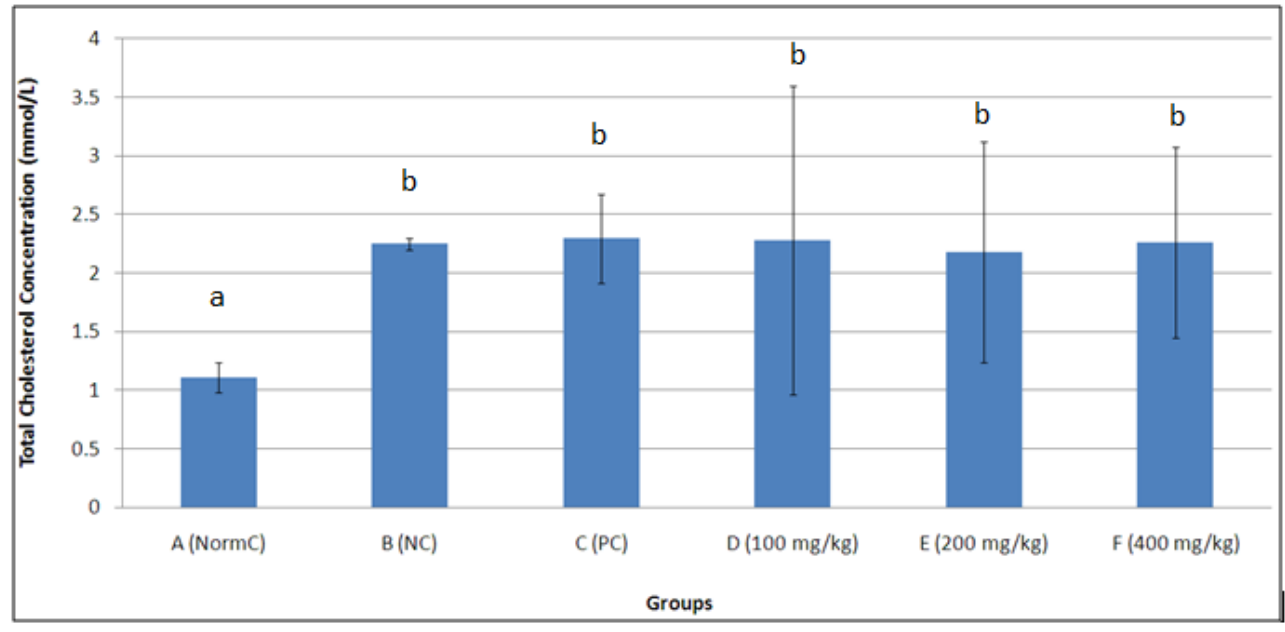

Figure 4. Total cholesterol concentration in rat's plasma treated with $M y P$ water extract for 4 weeks. Results are expressed as mean \pm S.D. Different superscripted letters on top of the chart indicate statistical differences $(p<0.05) . n=6$.

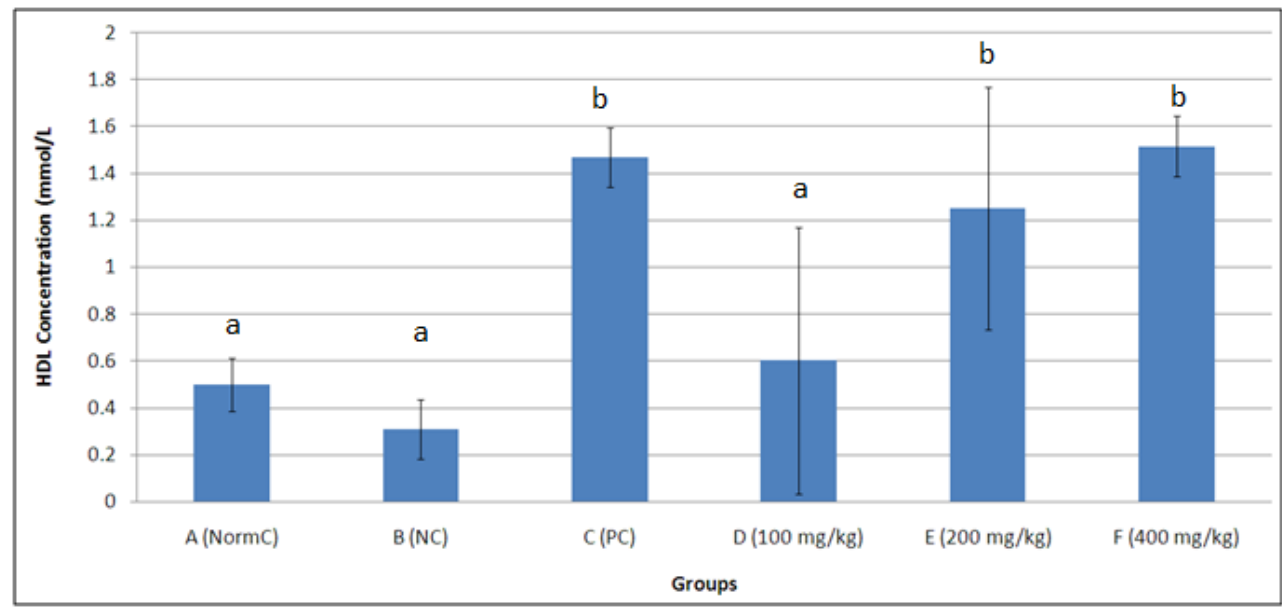

Figure 5. HDL concentration in rat's plasma treated with $M y P$ water extract for 4 weeks. Results are expressed as mean \pm S.D. Different superscripted letters on top of the chart indicate statistical differences $(p<0.05) . n=6$. 


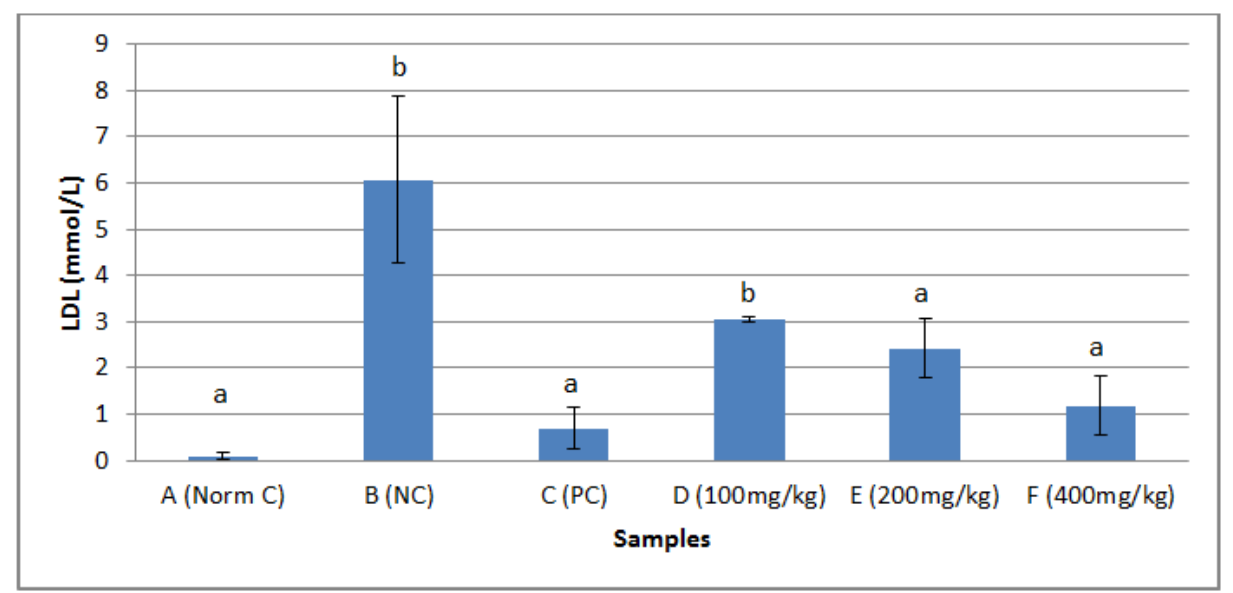

Figure 6. LDL concentration in rat's plasma treated with $M y P$ water extract for 4 weeks. Results are expressed as mean \pm S.D. Different superscripted letters on top of the chart indicate statistical differences $(p<0.05) . n=6$.

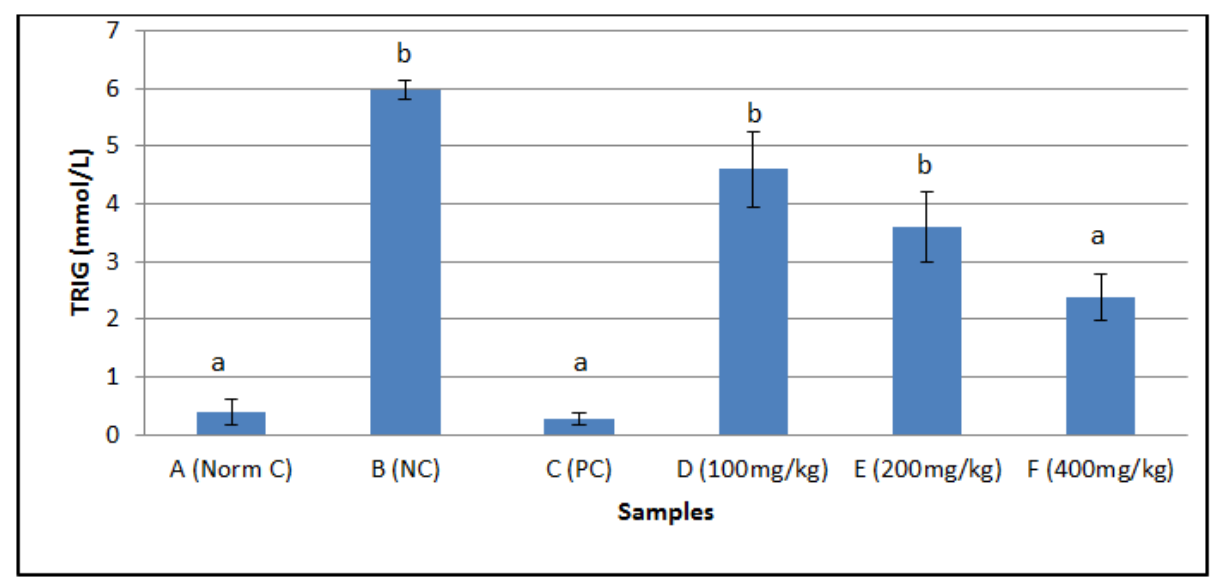

Figure 7. Triglyceride in rat's plasma treated with $M y P$ water extract for 4 weeks. Results are expressed as mean \pm S.D. Different superscripted letters on top of the chart indicate statistical differences $(\mathrm{p}<0.05) . \mathrm{n}=6$.

\section{Fecal Cholesterol Analyses}

Faecal cholesterol contents in rats treated with $M y P$ water extract for 4 weeks.

\begin{tabular}{|c|c|c|c|c|c|c|}
\hline \multirow[t]{2}{*}{ Group } & \multirow[t]{2}{*}{ Norm C } & \multirow[t]{2}{*}{$\mathrm{NC}$} & \multirow[t]{2}{*}{$\mathrm{PC}$} & \multirow{2}{*}{$\begin{array}{c}(100 \mathrm{mg} / \mathrm{kg}) \\
M y P \text { water } \\
\text { extract }\end{array}$} & \multirow{2}{*}{$\begin{array}{c}(200 \mathrm{mg} / \mathrm{kg}) \\
M y P \text { water } \\
\text { extract }\end{array}$} & \multirow{2}{*}{$\begin{array}{c}(400 \mathrm{mg} / \mathrm{kg}) \\
M y P \text { water } \\
\text { extract }\end{array}$} \\
\hline & & & & & & \\
\hline \multicolumn{7}{|c|}{ Dry weight } \\
\hline g/day & 5.2 & 6.1 & 5.4 & 6.34 & 5.87 & 5.94 \\
\hline \multicolumn{7}{|c|}{ Cholesterol } \\
\hline$(\mu \mathrm{mol} / \mathrm{g}$ & $4.17 \pm$ & $5.21 \pm$ & $5.27 \pm$ & $5.29 \pm$ & $7.91 \pm$ & $10.44 \pm$ \\
\hline feces) & $0.33 \mathrm{a}$ & $0.47 \mathrm{a}$ & $0.61 \mathrm{a}$ & $0.20 \mathrm{a}$ & $0.11 \mathrm{~b}$ & $0.14 \mathrm{c}$ \\
\hline \multicolumn{7}{|c|}{ Triglyceride } \\
\hline$(\mu \mathrm{mol} / \mathrm{g}$ & $4.65 \pm$ & $5.53 \pm$ & $5.62 \pm$ & $6.43 \pm$ & $8.83 \pm$ & $8.89 \pm$ \\
\hline feces) & $0.26 \mathrm{a}$ & $0.25 \mathrm{~b}$ & $0.31 \mathrm{a}$ & $0.43 c$ & $0.13 \mathrm{c}$ & $0.09 \mathrm{~b}$ \\
\hline
\end{tabular}

Table 1: Results are expressed as mean \pm S.D. Different superscripted letters indicate statistical differences $(\mathrm{p}<0.05) . \mathrm{n}=6$. 


\section{Fecal Bile Acid Analyses}

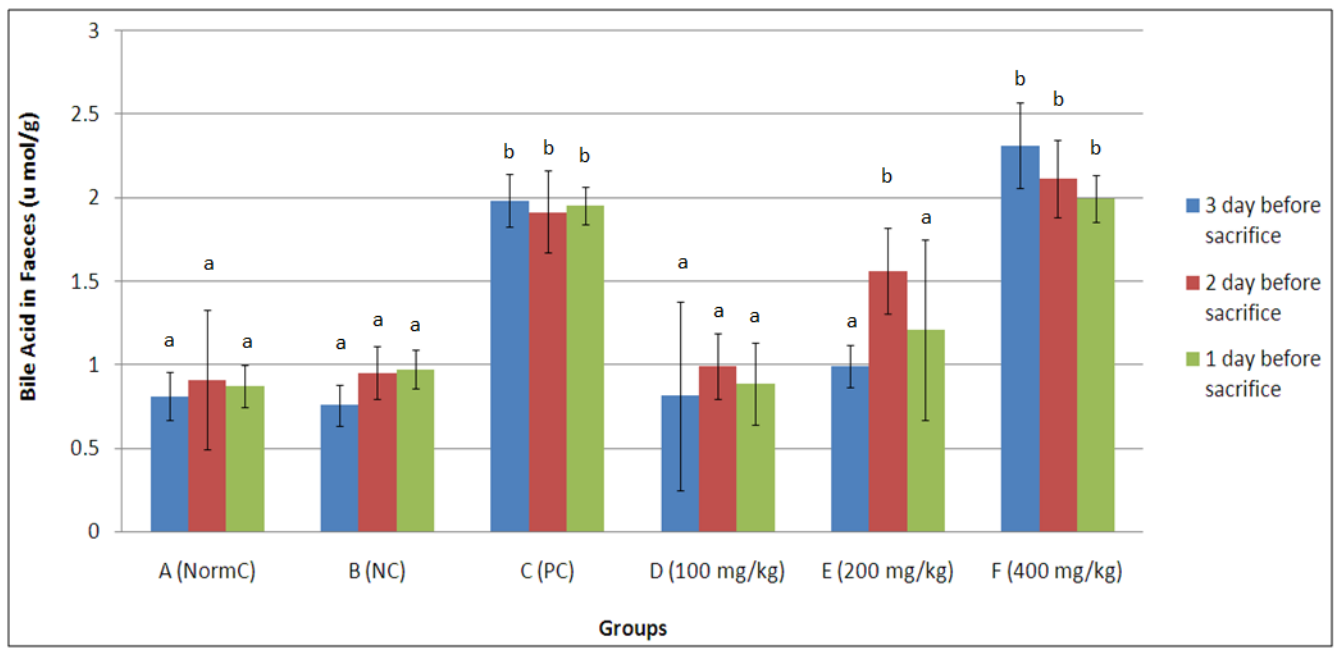

Figure 8. The concentration of total faecal bile in faeces of rats fed HCD and treated with $M y P$ water extract. The values represent the means $\pm S D$. Different superscripted letters in columns indicate statistical differences $(\mathrm{p}<0.05) . \mathrm{n}=6$.

AST

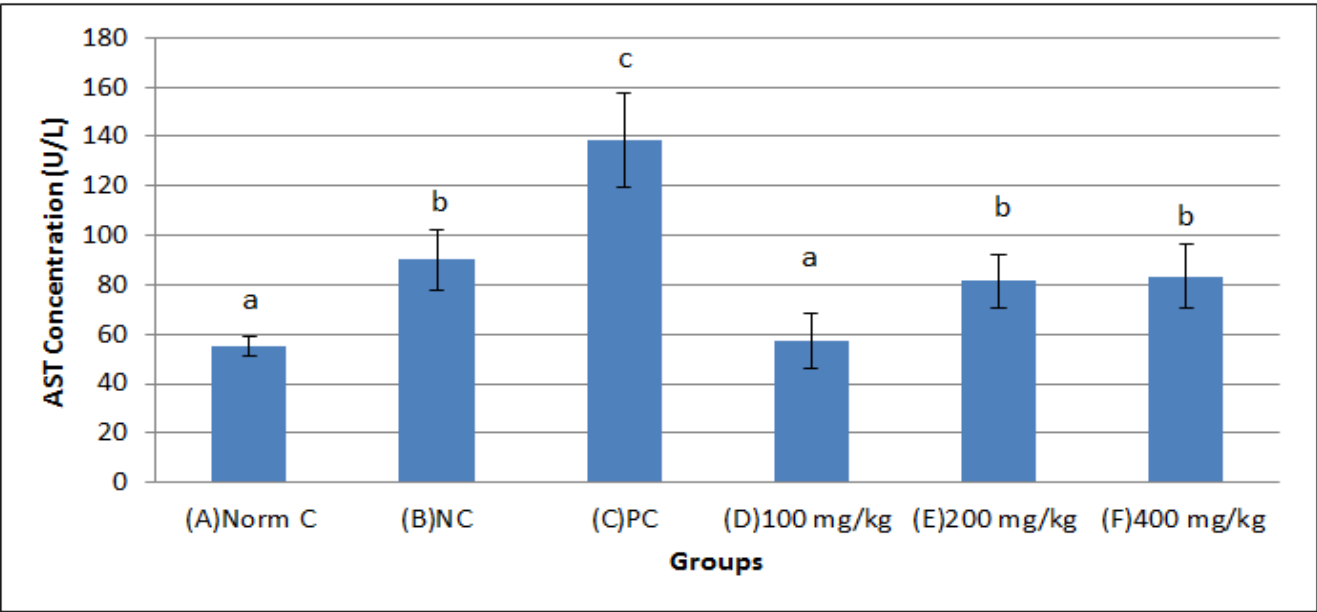

Figure 9. AST concentration in rat's plasma treated with $M y P$ water extract for 4 weeks. Results are expressed as mean \pm S.D. Different superscripted letters on top of the chart indicate statistical differences $(p<0.05) . n=6$.

ALT

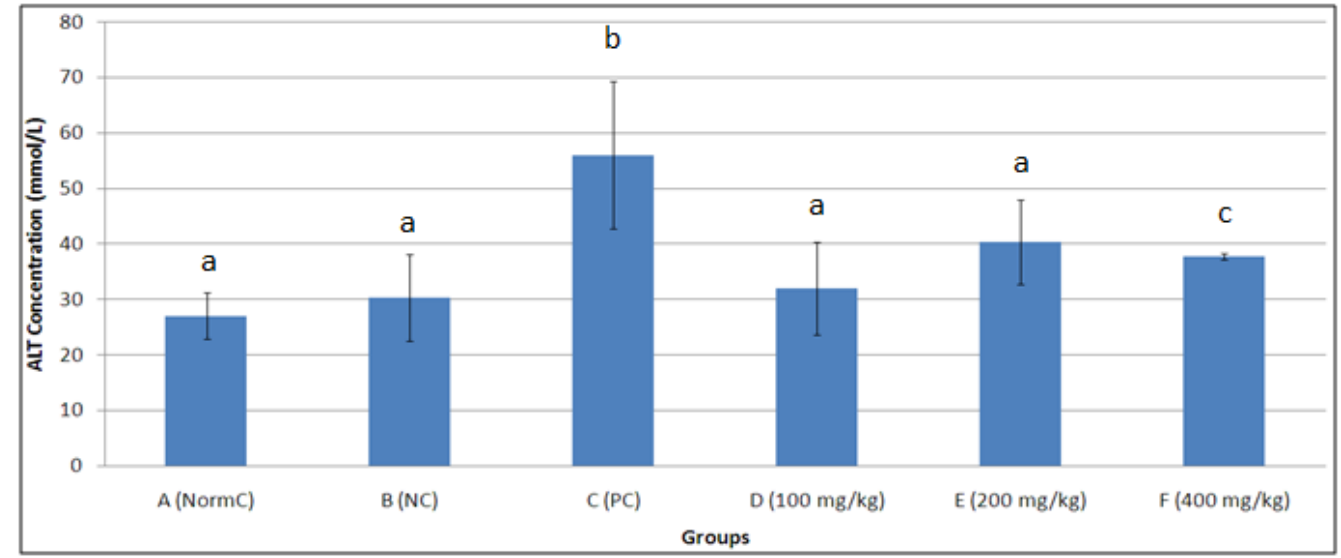

Figure 10. ALT concentration in rat's plasma treated with $M y P$ water extract for 4 weeks. Results are expressed as mean \pm S.D. Different superscripted letters on top of the chart indicate statistical differences $(p<0.05) . n=6$. 


\section{ALP}

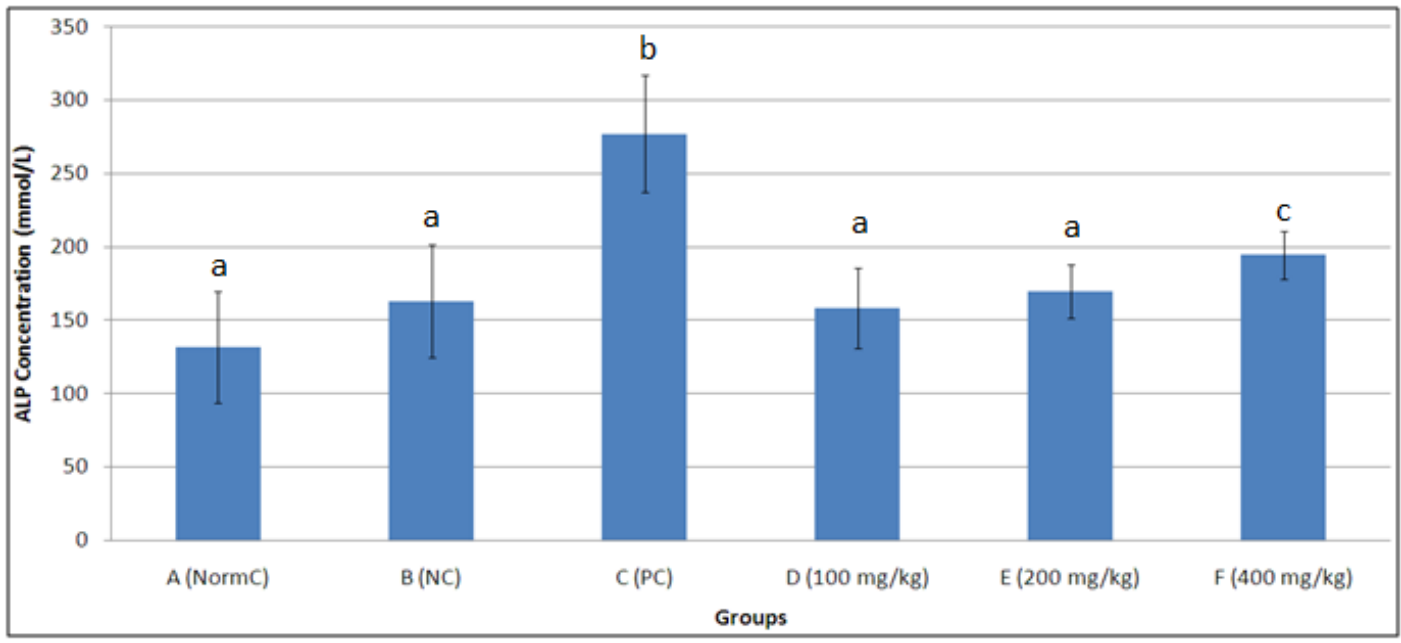

Figure 11. ALP concentration in rat's plasma treated with $M y P$ water extract for 4 weeks. Results are expressed as mean \pm S.D. Different superscripted letters on top of the chart indicate statistical differences $(p<0.05) . n=6$.

\section{Creatinine Kinase (CK)}

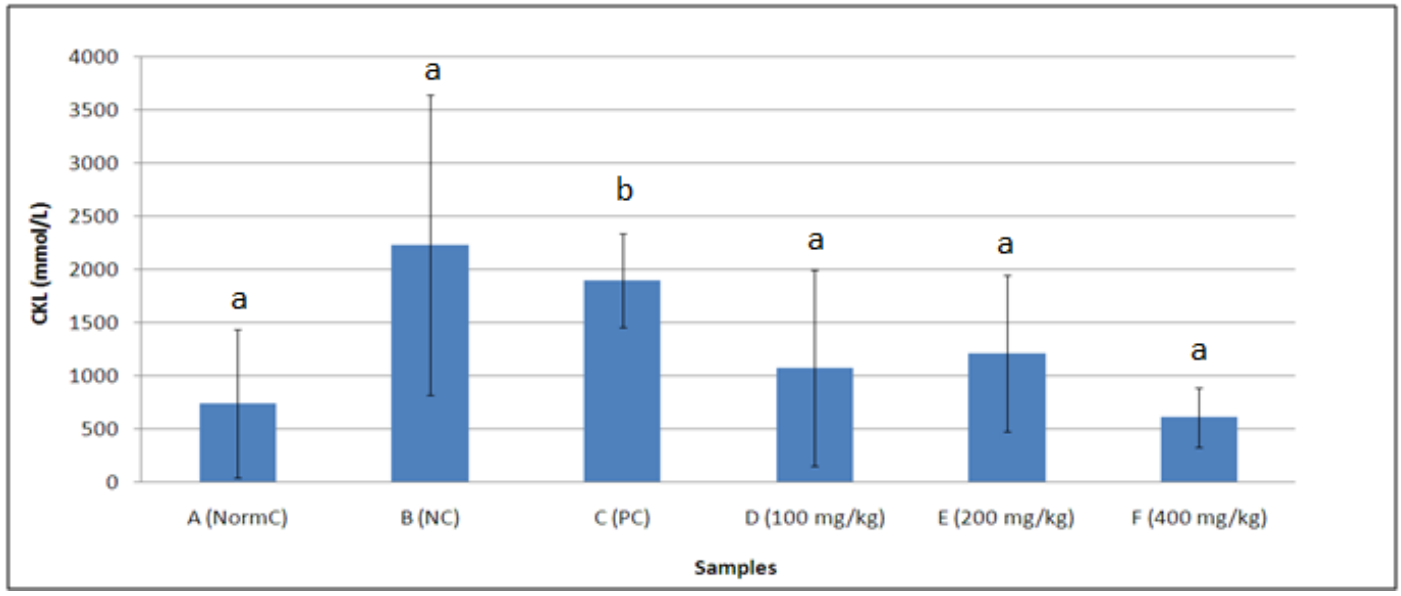

Figure 12. CK concentration in rat's plasma treated with $M y P$ water extract for 4 weeks. Results are expressed as mean \pm S.D. Different superscripted letters on top of the chart indicate statistical differences $(p<0.05) . n=6$.

\section{Urea}

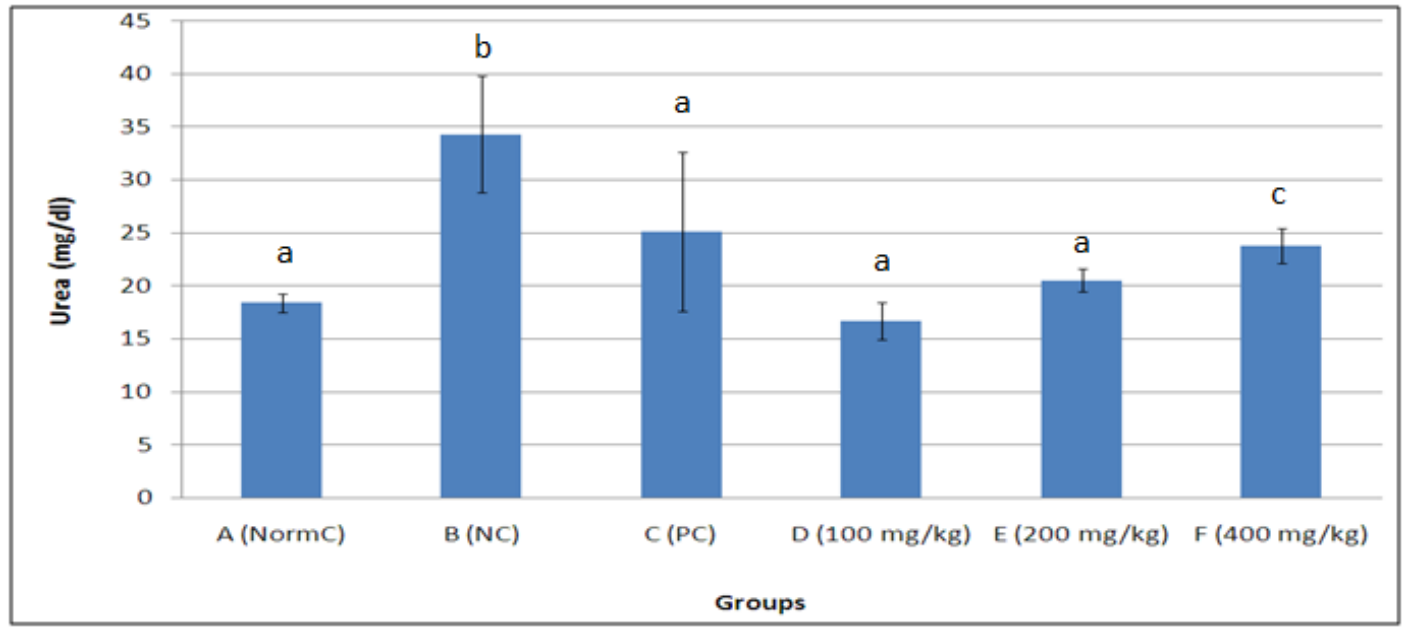

Figure 13. Urea concentration in rat's plasma treated with $M y P$ water extract for 4 weeks. Results are expressed as mean \pm S.D. Different superscripted letters on top of the chart indicate statistical differences $(p<0.05)$. $n=6$. 


\section{Discussion}

Nowadays, herbal medicines have become increasingly popular around the world (Popović et al., 2016). These medicines are among the most widely used as alternative treatments for many diseases (Tshitenge et al., 2016). However, their effectiveness, safety, and mechanism of actions largely remain unknown (Tshitenge et al., 2016; Snow, 2016). There are many herbs were developed as a nutraceutical and pharmaceutical product to reduce hypercholesterolemia (Chan et al., 2016; Mannarino et al., 2014).

One of the strategies that have been used to control blood cholesterol is controlling food intake containing cholesterol (Koopmans et al., 2015). Controlling food intake containing high cholesterol is literally decrease cholesterol absorption by intestine (Obrowsky et al., 2012; Vučić and Cvetković, 2016). As shown in Figure 1, there was no difference among groups on the amount of daily food intake in week 1 . However, $200 \mathrm{mg} / \mathrm{kg} M y P$ water extract treatment showed a decline of food intake in week 2. Meanwhile, other groups did not show any significant change compared to normal control in week 2. In week 3, PC and all MyP water extract treatment groups showed a decrease in food intake. Though, food intake pattern was increased tremendously in week 4 in all $M y P$ water extract treatment groups compared to week 3. This showed that $M y P$ extract can affect the food intake of the rat. However, the impact was not as good as a positive group. Food intake of PC group was decreased and maintained in week 4. As shown in Figure 2, water intake of $M y P$ water extract treated rat was decreased in week 1, week 2 and week 3 and gradually increased in week 4 . Treatment of $400 \mathrm{mg} / \mathrm{kg} M y P$ water extract showed inclined of water intake in week 4 . The normal group showed gradually decreased of water intake from week to week.

Besides that, Figure 3 showed the bodyweight of the rat was not significantly different compared to each group. Bodyweight of rat is related to animal's health (Bhardwaj et al., 2010). Within 4 weeks, almost all rats increase bodyweight from $250 \mathrm{~g}$ to $350 \mathrm{~g}$. There were no tremendous decreased of bodyweight reported within 4 weeks. This indicated that $M y P$ water extract was not toxic. Besides that, the levels of plasma TC were all significantly increased in the NC, MyP water extract and PC group compared to the normal group ( $\mathrm{p}<0.05)$. There were significant differences between the normal control and positive group (Figure 4). The PC showed a higher reading of TC. However, no significant differences were exhibited between the normal group and $M y P$ water extract treated group for $100 \mathrm{mg} / \mathrm{kg}$ and $200 \mathrm{mg} / \mathrm{kg}$ after 4 weeks of the experimental diet $(\mathrm{p}<0.05)$. As a reference value, the plasma TC level measured in rats fed a normal diet was $1.1 \mathrm{mmol} / \mathrm{l}$.

The $M y P$ water extract treated group exhibited a dramatic increment in the levels of plasma HDL after 4 weeks of treatment with $100 \mathrm{mg} / \mathrm{kg}, 200 \mathrm{mg} / \mathrm{kg}$ and $400 \mathrm{mg} / \mathrm{kg}(\mathrm{p}<0.05)$ as shown in Figure 5. The HDL concentration values in the normal control and NC group were significantly lower than PC group $(\mathrm{p}<0.05)$. The supplementation of $M y P$ water extract $(200 \mathrm{mg} / \mathrm{kg}$ and $400 \mathrm{mg} / \mathrm{kg}$ ) and Simvastatin for 4 weeks significantly increased $(\mathrm{p}<0.05)$ the levels of plasma HDL. However, the plasma HDL concentration was significantly lower in only $100 \mathrm{mg} / \mathrm{kg} M y P$ water extract group ( $\mathrm{p}<0.05)$. This indicated that treatment of $M y P$ water extract could help in HDL formation. Higher concentration of HDL in blood circulation might reduce the premature development of atherosclerosis and cardiovascular disease (Singh et al., 2007). Plasma levels of HDL are positively correlated with the function of anti-atherosclerosis (Lazo-Porras et al., 2015). In many reports, it was clearly suggested the mechanism of the anti-atherogenic effects of HDL are predominantly related to its contribution in the pathways of reverse cholesterol transport (RCT) (Mei and Atkinson, 2015).

In Figure 6, plasma LDL in the negative group showed significant higher compared to the normal group. However, PC group exhibited significant lower of LDL concentration compared to NC group $(\mathrm{p}<0.05)$. The levels of plasma LDL were significantly decreased in the $200 \mathrm{mg} / \mathrm{kg}$ and $400 \mathrm{mg} / \mathrm{kg} \mathrm{MyP} \mathrm{water} \mathrm{extract} \mathrm{treatment} \mathrm{groups.} \mathrm{Meanwhile,} \mathrm{the}$ concentration of plasma LDL was higher in only $100 \mathrm{mg} / \mathrm{kg} M y P$ water extract group than the other $M y P$ water extract groups. It was clearly observed that the $M y P$ water extract treatment's concentration has the impact in reducing LDL concentration level in the rat's blood circulation. According to Jones et al., (1996), dietary cholesterol suppresses the cholesterol biosynthesis. However, dietary cholesterol slightly raises plasma concentrations (Jones, 1997). The result of LDL level increase in rat induced with HCD was supported by Jones (1997). The LDL cholesterol plays a key role in the formation of plaque atheroma. Higher concentration of LDL level in the blood circulation increases the chance of lipid peroxidation by free radical.

Besides that, treatment of $400 \mathrm{mg} / \mathrm{kg} M y P$ water extract was effectively decreased the TG level in the rat. Meanwhile, no significantly differences were found in the plasma TG concentrations (Figure 7) in 100 and $200 \mathrm{MyP}$ water extract treatment group compared NC group. From the graph, it also can be seen that the TG concentration in NC group was a significant difference compared to the normal group. This occurred because of the diet that was induced to the rat containing fat. This finding was supported by the similar study that was performed by Buettner et al., (2006) which showed that induction of $42 \%$ fat can increase TG in the bloodstream, hepatosteatosis and accumulation of lipid droplet 
in the liver. Pancreatic lipase (triacylglycerol acyl hydrolase) catalyses the digestion of dietary fat (Seyedan et al., 2015). It is an important lipolytic enzyme which is synthesised and secreted by the pancreas and plays a significant role in dietary TG absorption, hydrolyzing TG to monoacylglycerols and fatty acids (Seyedan et al., 2015). The effect of MyP water extract has occurred at the intestine which it decreased the digestion of fat that was ingested by the rat. The undigested fat was carried out as faecal triglyceride as shown in Table 1. The faecal triglyceride was increased when the concentration of $M y P$ water extract was increased.

Moreover, the defecation process that brings out undigested cholesterol and lipid group also reducing blood cholesterol level. This occurs when the digestion and absorption process of cholesterol is interrupted by reducing pancreatic lipase enzyme activity and binding of bile acids. The rats treated with $100 \mathrm{mg} / \mathrm{kg} M y P$ water extract had increased faecal weight (dry) but did not significantly increase $(\mathrm{p}<0.05)$ faecal cholesterol excretion as compared to negative control. However, the faecal cholesterol excretion for the rats fed with the 200 and $400 \mathrm{mg} / \mathrm{kg} M y P$ water extract was significantly higher than NC group (Table 1). Correspondingly, the concentrations of faecal triglyceride in groups treated with $200 \mathrm{mg} / \mathrm{kg}$ and $400 \mathrm{mg} / \mathrm{kg} \mathrm{MyP}$ water extract were significantly higher $(\mathrm{p}<0.05)$ than NC group. This indicated that the concentration of $M y P$ water extract is the factor to increase the effect.

The excretion of bile acid (BA) in the group of $400 \mathrm{mg} / \mathrm{kg} M y P$ water extract treatment was approximately 2-fold higher than that in the normal and NC groups (Figure 8). The $M y P$ water extract treatment significantly increased $(p<0.05)$ the bile excretion from the intestine. These results suggested that there was an elevated of BA binding capacity in the $M y P$ water extract group which can result in a decrease of the hepatic pool of BA and a reduction of LDL. However, the binding capacity of BA only effective in highest $M y P$ water extract treatment group. Meanwhile, treatment for the other two concentrations did not significantly increase the BA excretion. The group that was treated with simvastatin in PC group showed the elevation of BA excretion. The higher amount of cholesterol in the faeces of the $400 \mathrm{mg} / \mathrm{kg} \mathrm{MyP}$ water extract group compared to the amount of cholesterol in the faeces of the NC group can be observed in Table 1.

Bile acids act as detergents and are responsible for facilitating the absorption of dietary lipids and fat-soluble vitamins, and for maintaining cholesterol homoeostasis in the body (Jones et al., 2015). In enterohepatic circulation, almost $95 \%$ of bile acids are efficiently reabsorbed from the intestinal lumen and undergo a recycling mechanism to be used for maintaining of cholesterol level in the body (Gannasin et al., 2016). Bile acid binding property of $M y P$ water extract is believed can lower down the level of bile acids reabsorption and increase the level of its excretion. Thus, hepatic synthesis of bile acids from blood cholesterol is increasing and leading to a reduction in blood cholesterol level (Gannasin et al., 2016). This effect may be responsible for the lowering LDL concentration observed in the MyP water extract group compared with the normal and negative group as can be seen in Figure 6. Besides that, bile acid also involves in triglyceride absorption at the intestinal lumen. Emulsification of lipid by bile acid is the vital process before it can be broken down by lipase enzyme. According to Sarkar et al., (2016) bile salts play a crucial role in lipid digestion by pushing initially adsorbed materials from the interface and permitting lipase/colipase complexes to act on the bilecoated oil droplets. This allows the process of lipid digestion which involve the breakdown of fat into small triglyceride and glycerol that can be absorbed by the enterocyte membrane. Figure 7 showed that the treatment of $400 \mathrm{mg} / \mathrm{kg} M y P$ water extract significantly decreased the level of triglyceride compared to NC. The undigested fat might be excreted by defecation which increased the faecal triglyceride as shown in Table 1.

Moreover, both ALT and AST transaminases are markers of hepatocyte injuries (Stolf et al., 2012). The results showed the plasma AST and ALT levels significantly decreased $(p<0.05)$ in PC group compared to normal control group. This result was supported by the previous study done by Torcha et al., (2010) and Sancho et al., (2013). There were consistently reported that Simvastatin increases ALT concentration. ALT is a sensitive measure of liver injury, broadly used to assess potential hepatotoxicity during drug development (Moylan et al., 2012). Figure 9 showed that the oral administration of $M y P$ water extract $(200$ and $400 \mathrm{mg} / \mathrm{kg}$ ) showed significantly decrease $(\mathrm{p}<0.05)$ of plasma AST levels compared to PC, whereas administration of $100 \mathrm{mg} / \mathrm{kg}$ showed no significant of AST compared with normal group. Interestingly, Figure 10 showed that treatment of $100 \mathrm{mg} / \mathrm{kg} M y P$ water extract showed significantly decrease $(\mathrm{p}<0.05)$ in ALT $(59.91 \pm 2.85$ and $32.47 \pm 1.23 \mathrm{U} / \mathrm{mL})$ levels.

The plasma levels of ALP in treated rat groups are given Fig 11 showed significantly increased in PC group. The plasma levels of ALP were significantly low in MyP water extract treated rats in comparison with PC group. Conversely, the plasma levels of ALP were significantly lower in the normal group. The liver enzymes, ALT, AST and ALP activities were significantly elevated in PC group in comparison with normal and NC group. These enzymes were significantly reduced in low and medium concentration of $M y P$ water extract treated rats comparing with PC group.

The elevation of the plasma levels of urea and CK are considered as significant markers of renal dysfunction (Davis et al., 2013; Sereno et al., 2013). The results in Figure 12 showed significant $(p<0.05)$ increase in the level of plasma CK in 
the negative group. While, after the treatment of Simvastatin the level of CK was significantly $(\mathrm{p}<0.05)$ increased in plasma compared with the normal group. Similarly, the elevation of CK level caused by HCD was declined after the administration of the $200 \mathrm{mg} / \mathrm{kg}$ and $400 \mathrm{mg} / \mathrm{kg} \mathrm{MyP}$ water extract by 28,31 and $39 \%$ ( $\mathrm{P}<0.05)$, respectively, compared with the negative group. Besides that, Figure 13 showed the treatment of $100 \mathrm{mg} / \mathrm{kg} \mathrm{MyP}$ water extract showed significantly decrease $(\mathrm{p}<0.05)$ the urea and CK levels. Treatment of $M y P$ water extract $200 \mathrm{mg} / \mathrm{kg}$ and $400 \mathrm{mg} / \mathrm{kg}$ showed significantly decrease $(\mathrm{p}<0.05)$ the $\mathrm{CK}$ while treatment of $400 \mathrm{mg} / \mathrm{kg}$ showed a significant increase $(\mathrm{p}<0.05)$ on the level of urea compared with normal control group. Generally, almost all biochemistry data showed that $M y P$ water extract was not toxic.

\section{CONCLUSION}

From this in vivo animal study, MyP water extract was able to reduce LDL cholesterol concentration in blood circulation significantly compared to NC group. The standardised extract also can increase bile excretion and increase HDL concentration. Altogether, these events are signs that MyP water extract may have the potential to actively preventing hypercholesterolemia related diseases, especially atherosclerosis. Interestingly, the finding of rising of HDL level might show that $\mathrm{MyP}$ water extract can increase the reverse cholesterol transport process.

\section{REFERENCES}

Bhardwaj, S., Srivastava, M.K., Kapoor, U., Srivastava, L.P., (2010). A 90 days oral toxicity of imidacloprid in female rats: Morphological, biochemical and histopathological evaluations. Food and Chemical Toxicology, 48(5):1185-1190.

Bordoloi, M., Bordoloi, P.K., Dutta, P.P., Singh, V., Nath, S., Narzary, B., Bhuyan, P.D., Rao, P.G., Barua, I.C., (2016). Studies on some edible herbs: Antioxidant activity, phenolic content, mineral content and antifungal properties. Journal of Functional Foods, 23: 220-229.

Buettner, R., Parhofer, K.G., Woenckhaus, M., Wrede, C.E., Kunz-Schughart, L.A., Schölmerich, J., \& Bollheimer, L.C. (2006). Defining high-fat-diet rat models: metabolic and molecular effects of different fat types. J Mol Endocrinol, 36(3):485-501.

Cao, S., Zhou, Y., Xu, P., Wang, Y., Yan, J., Bin, W., Qiu, F., Kang, N., (2013). Berberine metabolites exhibit triglyceride-lowering effects via activation of AMP-activated protein kinase in Hep G2cells. Journal of Ethnopharmacology, 149(2):576-582.

Chan, N., Li, S., Perez, E., (2016). Chapter 61 - Interactions between Chinese Nutraceuticals and Western Medicines. Nutraceuticals, 875-882

Davis, M.A., Eldridge, S., Louden, C., (2013). Chapter 10 - Biomarkers: Discovery, Qualification and Application. Haschek and Rousseaux's Handbook of Toxicologic Pathology (Third Edition), I: 317-352.

de Isla P.L., R. Alonso, G.F. Watts, N. Mata, A.S. Cerezo, O. Muñiz, F. Fuentes, J. L.Diaz-Diaz, R. de Andrés, D. Zambón, P. RubioMarin, M.A. Barba-Romero, P. Saenz, J.F. S. Muñoz-Torrero, C. Martinez-Faedo, J.P. Miramontes-Gonzalez, L. Badimón, P. Mata, SAFEHEART Investigators, (2016). Attainment of LDL-Cholesterol Treatment Goals in Patients with Familial Hypercholesterolemia: 5-Year SAFEHEART Registry Follow-Up. Journal of the American College of Cardiology, 67(11):1278-1285.

Engida, A.M., Kasim, N.S., Tsigie, Y.A., Ismadji, S., Huong, Huynh, L., Yi-Hsu J., (2013). Extraction, identification and quantitative HPLC analysis of flavonoids from sarang semut (Myrmecodia pendan). Industrial Crops \& Products, 41:392-396.

Gannasin, S.P., Mohd Adzahan, N., Mustafa, S., \& Muhammad, K. (2016). Techno-functional properties and in vitro bile acid-binding capacities of tamarillo (Solanum betaceum Cav.) hydrocolloids. Food Chemistry, 196:903-909.

Hamidpour, R., Hamidpour, M., Hamidpour, S., Shahlari, M., (2015). Cinnamon from the selection of traditional applications to its novel effects on the inhibition of angiogenesis in cancer cells and prevention of Alzheimer's disease, and a series of functions such as antioxidant, anticholesterol, antidiabetes, antibacterial, antifungal, nematicidal, acaracidal, and repellent activities. Journal of Traditional and Complementary Medicine, 5(2):66-70.

Hopkins, A.L., Lamm, M.G., Funk, J.L., Ritenbaugh, C., (2013). Hibiscus sabdariffa L. in the treatment of hypertension and hyperlipidemia: A comprehensive review of animal and human studies. Fitoterapia, 85:84-94.

Jones, H., Alpini, G., \& Francis, H. (2015). Bile acid signaling and biliary functions, Acta Pharmaceutica Sinica B, 5(2):123-128.

Jones, P.J. (1997). Regulation of cholesterol biosynthesis by diet in humans. Am J Clin Nutr, 66(2):438-46.

Jones, P.J., Pappu, A.S., Hatcher, L., Li, Z.C., Illingworth, D.R., \& Connor, W.E. (1996). Dietary cholesterol feeding suppresses human cholesterol synthesis measured by deuterium incorporation and urinary mevalonic acid levels. Arterioscler Thromb Vasc Biol, 16(10):1222-8

Koopmans, S.J., Schuurman, T., (2015). Considerations on pig models for appetite, metabolic syndrome and obese type 2 diabetes: From food intake to metabolic disease. European Journal of Pharmacology, 759: 231-239.

Lazo-Porras, M., Bernabe-Ortiz, A., Málaga, G., Gilman, R.H., Acuña-Villaorduña, A., Cardenas-Montero, D., Smeeth, L., \& Miranda, J.J. (2016). Low HDL cholesterol as a cardiovascular risk factor in rural, urban, and rural-urban migrants: PERU MIGRANT cohort study. Atherosclerosis, 246:36-43. 
Mannarino, M.R., Ministrini, S., Pirro, M., (2014). Nutraceuticals for the treatment of hypercholesterolemia. European Journal of Internal Medicine, 25(7):592-599.

Mei, X., \& Atkinson, D. (2015). Lipid-free Apolipoprotein A-I Structure: Insights into HDL Formation and Atherosclerosis Development. Archives of Medical Research, 46(5):351-360.

Mizaton, H.H., Haris, N.F.M., Mohd Zin, M., Mahamood, M., Ponto T., Abdul Wahab, I., Adam, A., (2014). Anti-inflammatory and immunomodulatary potential of Myrmecodia platytyrea tuber extract, The 3rd International Conference on Nutraceutical and Cosmetic Sciences, KEIO PLAZA HOTEL (Shinjuku), November 11 - 12.

Morita, M., Naito, Y., Yoshikawa, T., Niki, E., (2016). Plasma lipid oxidation induced by peroxynitrite, hypochlorite, lipoxygenase and peroxyl radicals and its inhibition by antioxidants as assessed by diphenyl-1-pyrenylphosphine. Redox Biology, 8:127-135.

Moylan, C.A., Suzuki, A., Papay, J.I., Yuen, N.A., Ames, M., Hunt, C.M., (2012). A pre-marketing ALT signal predicts post-marketing liver safety. Regulatory Toxicology and Pharmacology, 63(3):433-439.

Narasimhulu, C.A., Fernandez-Ruiz, I., Selvarajan, K., Jiang, X., Sengupta, B., Riad, A., Parthasarathy, S., (2016). Atherosclerosis do we know enough already to prevent it?. Current Opinion in Pharmacology, 27: 92-102.

Obrowsky S., Chandak, P.G., Patankar, J.V., Pfeifer, T., Povoden, S., Schreiber, R., Haemmerle, G., Levak-Frank, S., Kratky, D., (2012). Cholesteryl ester accumulation and accelerated cholesterol absorption in intestine-specific hormone sensitive lipase-null mice. Biochimica et Biophysica Acta (BBA) - Molecular and Cell Biology of Lipids, 1821(11):1406-1414.

Ogunremi, O.R., Sanni, A.I., Agrawal, R., (2015). Hypolipidaemic and antioxidant effects of functional cereal-mix produced with probiotic yeast in rats fed high cholesteroldiet. Journal of Functional Foods, 17:742-748.

Paun, G., Neagu, E., Albu, C., Moroeanu, V., Radu, G.L., (2016). Antioxidant activity and inhibitory effect of polyphenolic-rich extract from Betonica officinalis and Impatiens noli-tangere herbson key enzyme linked to type 2 diabetes. Journal of the Taiwan Institute of Chemical Engineers, 60:1-7.

Popović, Z., Matić, R., Bojović, S., Stefanović, M., Vidaković, V., (2016). Ethnobotany and herbal medicine in modern complementary and alternative medicine: An overview of publications in the field of I \& C medicine 2001-2013. Journal of Ethnopharmacology, 181:182-192

Roslizawaty, Rusli, Rani, S., Zuraidawati, Armansyah, T., Zuhrawaty, Sayuti, A., (2015). The Effect of Ethanolic Extract of Ant Plant (Myrmecodia sp.) on Blood Cholesterol Level in hypercholesterolemic Male Rat (Rattus norvegicus). Jurnal Medika Veterinaria, 9:1.

Saba, E., Jeon, B.R., Jeong, D.H., Lee, K., Goo, Y.K., Kim, S.H., Sung, C.K., Roh, S.S., Kim, S.D., Kim, H.K., Rhee, M.H., (2016). Black ginseng extract ameliorates hypercholesterolemia in rats. Journal of Ginseng Research, 40(2):160-168.

Sancho, J.G., García-Calderó, H., Hide, D., Marrone, G., Guixé-Muntet, S., Peralta, C., García-Pagán, J.C., Abraldes, J.G., Bosch, J., (2013). Simvastatin maintains function and viability of steatotic rat livers procured for transplantation. Journal of Hepatology, 58(6):1140-1146.

Sarkar, A., Ye, A., \& Singh, H. (2016). On the role of bile salts in the digestion of emulsified lipids. Food Hydrocolloids, 60:77-84.

Sereno, J., Parada, B., Rodrigues-Santos, P., Lopes, P.C., Carvalho, E., Vala, H., Teixeira-Lemos, E., Alves, R., Figueiredo, A., Mota, A., Teixeira, F., Reis, F., (2013). Serum and Renal Tissue Markers of Nephropathy in Rats under Immunosuppressive Therapy: Cyclosporine versus Sirolimus. Transplantation Proceedings, 45(3):1149-1156.

Seyedan, A., Alshawsh M.A., Alshagga M.A., Koosha S., \& Mohamed, Z. (2015). Medicinal Plants and Their Inhibitory Activities against Pancreatic Lipase: A Review. Evidence-Based Complementary and Alternative Medicine, Article ID 973143, 13 pages.

Shodehinde, S.A., Oboh G., (2013). Antioxidant properties of aqueous extracts of unripe Musa paradisiaca on sodium nitroprusside induced lipid peroxidation in rat pancreas in vitro. Asian Pacific Journal of Tropical Biomedicine, 3(6):449-457.

Šibul, F., Orčić, D., Vasić, M., Anačkov, G., Nađpal, J., Savić, A., Mimica-Dukić, N., (2016). Phenolic profile, antioxidant and antiinflammatory potential of herb and root extracts of seven selected legumes. Industrial Crops and Products, 83:641-653.

Singh, I.M., Shishehbor, M.H., \& Ansell, B.J., (2007). High-density lipoprotein as a therapeutic target: a systematic review. JAMA, 298:786-798

Snow, J., (2016). Context Effects in Western Herbal Medicine: Fundamental to Effectiveness?, EXPLORE: The Journal of Science and Healing, 12(1):55-62.

Soeksmanto, A., Subroto, M.A., Wijaya, H., Simanjuntak, P., (2010). Anticancer Activity Test for Extracts of Sarang Semut Plant (Myrmecodya pendens) to HeLa and MCM-B2 Cells. Pakistan Journal of Biological Sciences, 13: 148-151.

Stolf, A.M., dos Reis Lívero, F., Dreifuss, A.A., Bastos-Pereira, A.L., Fabosi, I.A., de Souza, C.E.A., de Oliveira Gomes, L., Chicorski, R., Brandt, A.P., Cadena, S.M.S., Telles, J.E.Q., Hauser, A.B., Elferink, R.O., Zampronio, A.R., Acco, A., (2012). Effects of statins on liver cell function and inflammation in septic rats. Journal of Surgical Research, 178(2):888-897.

Tolani, S., Pagler, T.A., Murphy, A.J., Bochem, A.E., Abramowicz, S., Welch, C., Nagareddy, P.R., Holleran, S., Hovingh, G.K., Kuivenhoven, J.A., Tall, A.R., (2013). Hypercholesterolemia and reduced HDL-C promote hematopoietic stem cell proliferation and monocytosis: Studies in mice and FH children. Atherosclerosis, 229(1):79-85. 
Trocha, M., Merwid-Ląd, A., Chlebda, E., Pieśniewska, M., Sozański, T., Szeląg, A., (2010). Effect of simvastatin treatment on rat livers subjected to ischemia/reperfusion. Pharmacological Reports, 62(4):757-762.

Tshitenge, D.T., Ioset, K.N., Lami, J.N., Ndelo-di-Phanzu, J., Mufusama, J.P.K.S., Bringmann, G., (2016). Rational quality assessment procedure for less-investigated herbal medicines: Case of a Congolese antimalarial drug with an analytical report. Fitoterapia, 110: 189-195.

Vučić, V., and Cvetković, Z., (2016). Cholesterol: Absorption, Function and Metabolism. Reference Module in Food Science, from Encyclopedia of Food and Health, 47-52.

Xie, C., Kang, J., Burris, R., Ferguson, M.E., Schauss, A.G., Nagarajan, S., Wu, X., (2011). Açaí juice attenuates atherosclerosis in ApoE deficient mice through antioxidant and anti-inflammatory activities. Atherosclerosis, 216(2): 327-333.

$$
\text { -- } 0 \text {-- }
$$

